\title{
Aktifitas Fisik, Peran Orang Tua, Sumber Informasi terhadap Personal Hygiene saat Menstruasi pada Remaja Putri
}

\author{
Nur Khasanah \\ Program Studi Kebidanan Program Sarjana Terapan Departemen Kebidanan \\ Sekolah Tinggi Ilmu Kesehatan Indonesia Maju \\ Email corespondent: nurkhasanah11031996@gmail.com,
}

Hak Cipta:

(C)2021 Artikel ini memiliki akses terbuka dan dapat didistribusikan berdasarkan ketentuan Lisensi Atribusi Creative Commons, yang memungkinkan penggunaan, distribusi, dan reproduksi yang tidak dibatasi dalam media apa pun, asalkan nama penulis dan sumber asli disertakan. Karya ini dilisensikan di bawah Lisensi Creative Commons Attribution Share Alike 4.0 Internasional.
A B S T R A C T

Introduction: Di Amerika presentase kejadian perilaku personal hgine sekitar $60 \%$ swedia $72 \%$ dan di Indonesia $55 \%$. Berdasarkan hasil survey BKKBN provinsi jawa barat menunjukan bahwa $83 \%$ remaja tidak tahu tentang konsep kesehatan reproduksi yang benar $61,8 \%$ tidak tahu di persoalan masa subur dan masalah haid., kabupaten bogor salah satu dari beberapa kabupaten yang ada di jawa barat dengan personal hygiene yang kurang baik

Objectives: Tujuan penelitian ini untuk mengetahui hubungan aktifitas fisik peran orang tua sumber informasi terhadap personal hygiene saat menstruasi pada remaja putri di SMK Kusuma Bangsa Bogor Tahun 2020

Method: Penelitian ini menggunakan metode penelitian deskriptif analitik, pendekatan cross sectional, jumlah sampel 60 responden diperoleh dengan teknik total sampling. Data di olah menggunakan Program Komputer.

Results: Hasil uji tatistic Chi-square variabel aktifitas fisik $(\mathrm{P}$-value $=0,024)$, peran orang tua $(\mathrm{P}$-value $=0,000)$ sumber informasi (P-value $=0,003)$.

Conclusion: Kesimpulannya ada hubungan aktifitas fisik, peran orang tua, sumber informasi terhadap personal hygiene saat menstruasi pada remaja putri di SMK Kusuma Bangsa Bogor Tahun 2020

Keyword: aktifitas fisik, peran orang tua, sumber informasi, personal hygiene. 


\section{SIMFISIS Jurnal Kebidanan Indonesia}

Volume 01, Nomor 01, Agustus 2021

\section{Pendahuluan}

Masa remaja berawal dari usia 12 sampai dengan 24 tahun (WHO). Peraturan mentri kesehatana RI No 25 tahun 2014 menjelaskan remaja adalah penduduk dalam rentang usia 10-18 tahun. Sedangkan menurut BKKBN, 10 - 24 Tahun tergolong usia remaja dengan status belum melakukan pernikahan. Masa remaja merupakan masa tranasisi dari anak - anak kemasa dewasa dimana remaja sedang mengalami perubahan baik fisik maupun psikologis. ${ }^{1}$ Remaja akan melalui banyak peristiwa dalam tahap perkembangan dan pertumbuhan. Adapun peristiwa tersubut yaitu munculnya berbagai ciri alat kelamin sekunder meliputi tumbuh suburnya rambut pada area kewanitaan dan daerah ketiak, lingkar panggul melebar, mengalami mestruasi, mengencangnya ukuran payudara, kulit kian terasa halus dan lebih emosional. Seorang remaja putri akan menstruasi apabila system reproduksi dan berbagai komponen hormon yang berada ditubuh telah prima. ${ }^{2}$

Menstruasi ialah keluarnya darah diuterus, yang lumrah dialami oleh perempuan setiap bulan dan dibarengi proses peluruhan pada dindng rahim. Siklus menstruasi merupakan sejak hari pertama menstruasi sampai datangnya menstruasi priode berikutnya, sedangkan panjang siklus menstruasi adalah jarak antara tanggal mulainya mestruasi yang lalu dan mulainya menstruasi berikutnya. Siklus menstruasi pada wanita normalnya berkisar antara 21 - 35 hari dan hanya $10-15 \%$ yang memiliki siklus menstruasi 28 hari dengan lama menstruasi $3-5$ hari dan ada yang $7-8$ hari. ${ }^{3}$ Remaja Indonesia saat ini sedang mengalami peningkatan kerentanan terhadap berbagai ancaman resiko kesehatan yang berkaitan dengan kesehatan seksual dan reproduksi salah satunya adalah personal hygiene saat menstruasi, karena hygiene saat menstruasi sangat penting dilakukan karena jika tidak di terapkan dengan baik maka akan berdampak negative terhadap kesehatan reproduksi. ${ }^{4}$

Menurut WHO (2014) penduduk remaja berjumlah 1,2 milyar atau $18 \%$ dari jumlah penduduk dunia dan di perkirakan pada tahun 2030 populasi anak mudah usia 20 - 24 tahun adalah sekitar 1,9 milyar jiwa, WHO juga mengungkapkan angka kejadian perilaku personal hygiene saat menstruasi pada remaja putri yang buruk didunia sangatlah besar, rata - rata lebih dari $50 \%$ perempuan di dunia. Di Amerika presentase kejadian perilaku personal hygiene sekitar $60 \%$ swedia $72 \%$ dan di Indonesia 55 $\% .^{5}$ Data dinas kesehatan Indonesia bahwa jumlah remaja putri yang mengalami hygiene menstruasi yang buruk yaitu DKI Jakarta 30,3 \%, kota Yogjakarta 13,2 \%, Nusa Tenggara Barat 12,1 \% dan Nusa Tenggara Timur 8,9\% dan di Bengkulu 2,0\%. Berdasarkan hasil survey BKKBN provinsi jawa barat menunjukan bahwa $83 \%$ remaja tidak tahu tentang konsep kesehatan reproduksi yang benar 61,8 \% tidak tahu di persoalan masa subur dan masalah haid. Dan 40,6 \% tidak tau resiko kehamilan remaja dan 42,4 \%tidak tau tentang resiko PMS. ${ }^{6}$

Remaja putri rentang terkena infeksi organ reproduksi. Hal ini terjadi karena kurangnya perilaku dalam merawat kebarsihan diri terutama saat mengalami menstruasi. Remaja putri memiliki tingkat pengetahuan yang rendah terkait kesehatan reproduksi. ${ }^{2}$ Menurut penelitian yang dilakukan oleh purwanto 2012 di SLTP Bogor, yang melakukan perawatan genetalia secara benar pada saat tidak menstruasi sebesar 49,6 \% dan 45,5\% pada saat menstruasi. ${ }^{7}$ Menurut hasil dari penelitian yang dilakukan oleh wulandari dari tahun 2012 di dapatkan bahwa sumber informasi yang di terima oleh remaja putri berusia 13 hingga 16 tahun tentang perawatan alat reproduksi eksternal ketika menstruasi sebagian besar adalah cukup sejumlah $63 \%$. Selain itu perilaku dalam melakukan perawatan terhadap organ reproduksi eksternal yang mayoritas dalam frekuensi cukup, jumlahnya $48 \%$. Permasalahn ini disebabkan oleh rendahnya sumber informasi dan peran orang tua yang tidak begitu aktif. ${ }^{8}$ Sumber informasi yang di berikan memiliki tujuan yaitu penambahan informasi mengenai personal hygiene saat menstruasi. Materi tersebut. Perlu diutarakan kepada kelompok remaja putri. Oleh karena itu sumber informasi sangatlah penting baik itu informasi dari orang tua, guru, teman, media masa, media elektronik maupun media cetak. Sejalan dengan penelitian yang dilakukan oleh erni gistina DKK 2015 remaja mendapatkan sumber informasi tentang personal hygiene baik saat menstruasi atau tidak pada saat menstruasi dari ibu mereka sebanyak $81 \%$, dari guru dan teman sebaya sebanyak $15 \%$.

Selain sumber informasi Peran orang tua juga sangat penting dalam memberikan pengetahuan perilaku personal hygiene saat menstruasi pada remaja maka dari itu orang tua juga harus memiliki pengetahuan yang mendalam tentang personal hygiene saat menstruasi. Tingkat pendidikan orang tua 


\section{SIMFISIS Jurnal Kebidanan Indonesia}

Volume 01, Nomor 01, Agustus 2021

yang rendah dan kurang pengetahuan remaja tentang mestruasi sering dikira bahwa kesehatan pada reproduksi merupakan suatu perbincangan paling tabuh untuk diulas dengan detail dan mendalam. Pernyataan ini dipertegas oleh penelitian Anisa Citra dkk tahun 2018 bahwa peran orang tua sanagt penting atau baik sebesar $90,4 \%$ dari jumlah tersebut dapat diketahui bahwa mayoritas peran orang tua dengan baik sebai panutan dan sebagian kecil sebagai sumber informasi. Orang tua terutama ibu sangat penting dalam perkembangan remaja terutama pada kesehatan reproduksinya, remaja yang mendapatkan sumber informasi dan pendidikan kesehatan dari ibunya 2 kali lebih besar untuk melakukan personal hygiene yang baik dan benar saat menstruasi maupun tidak menstruasi. ${ }^{9}$

Personal hygiene adalah usaha dari setiap manusia yang wajib dilakukan dalam keseharian guna terpeliharanya kebersihan dan kesehatan diri, terkait secara fisik maupun psikologis dengan demikian perawatan terhadap tubuh harus dibiasakan minimal dengan mandi 2 kali dalam sehari. Menjaga kesehatan perinatal juga penting terlebih ketika menstruasi. Hal ini perlu karena saat menstruasi, kuman dan bakteri mudah masuk dan dapat mengidentivikasi organ vital perempuan. Berdasarkan suvei awal yang dilakukan pada siswi SMK Kusuma Bangsa Bogor di dapatkan dari 10 siswi yang dilakukan wawancara 6 siswa (60\%) tidak mengetahui cara personal hygiene yang baik dan benar, bahkan dari 6 siswi yang tidak mengetahui cara personal hygiene yang baik dan benar tersebut ada 4 siswi (40\%) diantaranya megalami keputihan dan merasakan gatal pada area kewanitaan. Berdasarkan data diatas peneliti tertarik melakukan penelitian di SMK Kusuma Bangsa Bogor karena terdapat masalah dari 10 siswi 6 siswi yang tidak mengetahui cara personal hygiene yang benar saat menstruasi, lalu ada juga diantara mereka yang menglami keputihan dan gatal di area kewanitaannya. Ada juga dari mereka yang kurang memperhatikan pembalutnya pada saat menstruasi sedangkan 4 siswi lainnya sudah mengerti cara personal hygiene yang benar dan kapan saja mereka harus mengganti pembalutnya.

Hasil studi pendahuluan latar belakang diatas dapat dirumuskan masalaha yaitu meningkatnya kebersihan diri pada remaja putri terutama pada saat menstruasi Di SMK Kusuma Bangsa Bogor. Karena masih banyak remaja yang tidak tau cara personal hygine yang baik dan benar. Pada akhir tahun 2018 terdapat 15 kasus personal hygine terutama pada saat menstruasi seperti infeksi saluran reproduksi, keputihan dan lain sebagainya, dan pada tahun 2019 terdapat 20 kasus personal hygine pada remaja putri jika tidak di tangani secara tepat akan membuat dampak negative bagi remaja tersebut.

\section{Metode}

Penelitian ini adalah jenis penelitian analitik deskriptifyaitu sesuai metode penelitian yang dilakukan dengan tujuan utama untuk mengetahui hubungan antara aktifitas fisik, peran orang tua, sumber informasi terhadap personal hygiene saat menstruasi pada remaja putri. Penelitian ini menggunakan pendekatan cross sectionaldengan cara poin time approach. Artinya variabel aktifitas fisik, peran orang tua dan sumber informasi diobservasi dan diukur pada saat bersamaan. ${ }^{10}$ Instrument penelitian ini menggunakan alat bantu berupa kuesioner yang dibuat berdasarkan teori yang ada, kuesioner adalah daftar pertanyaan yang sudah tersusun dengan baik dimana responden (dalam hal angket) dan interview (dalam hal wawancara) tinggal memberikan jawaban atau dengan memberikan tanda - tanda tertentu. Jenis kuesioner yang akan digunakan dalam penelitian ini adalah kuesioner dengan bentuk tertulis.

populasi adalah keseluruhan objek yang di teliti. Populasi dalam penelitian ini adalah remaja putri kelas X (Xa, Xb, Xc) di SMK Kusuma Bangsa Bogor yang berjumlah 60 orang Penelitian ini dilaksanakan pada bulan Januari-Februari tahun 2020 di SMK Kusuma Bangsa Bogor dan penelitian ini dilakukan pada remaja putri. Populasi adalah keseluruhan objek yang diteliti. ${ }^{10}$ Populasi dalam penelitian ini adalah remaja putri kelas X di SMK Kusuma Bangsa yang berjumlah 60 orang. Sampel adalah objek yang diteliti dan dianggap mewakili seluruh populasi. Sampel dalam penelitian ini adalah remaja putri Kelas X di SMK Kusuma Bangsa Bogor . Tehnik sampling yang digunakan adalah jenis non probability sampling, yaitu dengan total sampling (sampling jenuh) sehingga seluruh populasi diambil sebagai sampel. Sampel dalam penelitian ini yaitu Siswi Kelas X di SMK Kusuma Bangsa Bogor berjumlah 60 orang responden. 


\section{SIMFISIS Jurnal Kebidanan Indonesia}

Volume 01, Nomor 01, Agustus 2021

Kriteria inklusi adalah criteria atau cirri-ciri yang perlu dipenuhi oleh setiap anggota populasi yang dapat diambil sebagai sampel. Adapun criteria inklusi dalam penelitian adalah sebagai berikut : (a) Remaja Putri yang bersekolah di SMK Kusuma Bangsa Bogor Tahun 2019. (b) Remaja yang hadir saat penyebaran kuisioner. (c) Remaja yang bersedia mengisi kuisioner. Uji Coba Instrumen Sebelum alat ukur (kuisioner) digunakan maka terlebih dahulu dilakukan uji coba kuisioner yaitu uji validitas dan realibitas kuisioner penelitian . tujuan uji coba ini adalah untuk mengetahui apakah intrumen ini bisa digunakan apa tidak. Instrument yang benar-benar digunakan sebagai alat ukur mengetahui tingkat kehandalan hasil pengukuran yang dilakukan (reliable). ${ }^{11}$ Validitas merupakan suatu ukuran yang menunjukkan tingkat-tingkat validitas atau kesahilan suatu instrument. Suatu instrument yang valid atau sahih memiliki validitas tinggi. Sebaliknya, intrumen yang kurang valid berarti memiliki validitas yang rendah. Metode analisa data yang digunakan dalam penelitian adalah univariat dan bivariat. Analisis univariat dilakukan terhadap tiap variabel dari hasil penelitian.

\section{Hasil}

\section{Analisis Univariat}

Anaslisa univariat bertujuan untuk mendiskripsikan atau menjelaskan karakteristik setiap variabel penelitian . bentuk analisis univariat tergantung dari jenis datanya . pada umumnya dalam analisis ini hanya menghasilkan distribusi frekuensi dan presentase dari tiap variabel. ${ }^{12}$

Tabel 1 Distribusi Frekuensi personal hygiene, aktifitas fisik, peran orang tua, sumber informasi Remaja Putri Di SMK Kusuma Bangsa BogorTahun 2020

\begin{tabular}{lcc}
\hline Variabel & Frekuensi (f) & Persentase (\%) \\
\hline Personal Hygine & & \\
Bersih & 28 & $46,7 \%$ \\
Kurang Bersih & 32 & $53,3 \%$ \\
Aktifitas Fisik & & \\
Tidak Sering & 37 & $61,7 \%$ \\
Sering & 23 & $38,3 \%$ \\
Peran orang tua & & \\
$\quad$ Tidak Berperan & 31 & $51,7 \%$ \\
Berperan & 29 & $48,3 \%$ \\
Sumber informasi & & \\
$\quad$ Tidak & 34 & $56,7 \%$ \\
Ya & 26 & $43,3 \%$ \\
Peran orang tua & & \\
Tidak Berperan & 31 & $51,7 \%$ \\
\hline
\end{tabular}

Sumber : Pengolahan data 2020

Berdasarkan tabel 1 distribusi frekuensi terbesar dari variabel personal hygieneremaja putri di SMK Kusuma Bangsa Bogor tahun 2020adalah 32 responden (53,3\%)melakukan personal hygiene kurang bersih. Distribusi frekuensi terbesar dari variabel aktifitas fisikremaja putri di SMK Kusuma Bangsa Bogor tahun 2020adalah 37 responden $(61,7 \%)$ tidak sering melakukan aktifitas fisik. Distribusi frekuensi terbesar dari variabel peran orang tua remaja putri di SMK Kusuma Bangsa Bogor tahun 2020adalah 31 responden (51,7\%) orantua tidak berperan. Distribusi frekuensi terbesar dari variabel sumber informasi remaja putri di SMK Kusuma Bangsa Bogor tahun 2020adalah 34 responden (56,7\%) tidak mendapatkan sumber informasi.

\section{Analisis Bivariat}

Analisa Bivariat dilakukan untuk mengetahui distribusi frekuensi dan presentase dari variabel dependen ( Personal Hygine) dan variabel independen ( Aktivitas Fisik,Peran Orang Tua, dan Sumber Informasi) pada Siswi SMK Kusuma Bangsa Bogor Tahun 2020 dengan Tingkat Kemaknaan a = 0,05 
Tabel 2 . Hubungan aktifitas fisik, peran orangtua, sumber informasi terhadap personal hygiene saat menstruasi pada remaja putrid di SMK Kusuma Bangsa Bogor tahun 2020

\begin{tabular}{|c|c|c|c|c|c|c|c|c|}
\hline \multirow{3}{*}{ Variabel Penelitian } & \multicolumn{4}{|c|}{$\begin{array}{c}\text { Personal Hygiene Saat } \\
\text { Menstruasi }\end{array}$} & \multirow{2}{*}{\multicolumn{2}{|c|}{ Total }} & \multirow{3}{*}{$\begin{array}{c}\mathbf{P} \\
\text { Value }\end{array}$} & \multirow{3}{*}{ OR } \\
\hline & \multicolumn{2}{|c|}{ Bersih } & \multicolumn{2}{|c|}{ Kurang Bersih } & & & & \\
\hline & $\mathbf{F}$ & $\%$ & $\mathbf{F}$ & $\%$ & $\mathbf{F}$ & $\%$ & & \\
\hline \multicolumn{9}{|l|}{ Aktifitas fisik } \\
\hline Tidak Sering & 22 & $59.5 \%$ & 15 & $40.5 \%$ & 37 & 100 & 0,024 & 4.156 \\
\hline Sering & 6 & $26.1 \%$ & 17 & $73.9 \%$ & 23 & 100 & & \\
\hline \multicolumn{9}{|l|}{ Peran orang tua } \\
\hline Tidak Berperan & 23 & $74.2 \%$ & 8 & $25.8 \%$ & 31 & 100 & 0,000 & 13,800 \\
\hline Berperan & 5 & $17.2 \%$ & 24 & $82.8 \%$ & 29 & 100 & & \\
\hline \multicolumn{9}{|l|}{ Sumber informasi } \\
\hline Tidak & 22 & $64.7 \%$ & 12 & $35.3 \%$ & 34 & 100 & 0,003 & 6,111 \\
\hline Ya & 6 & $23.1 \%$ & 20 & $76.9 \%$ & 26 & 100 & & \\
\hline
\end{tabular}

Sumber : Pengolahan data 2020

Berdasarkan tabel 2 dapat dijelaskan bahwa dari 37 responden dengan aktifitas fisik tidak sering dengan melakukan personal hygiene bersih yaitu sebanyak 22 responden (59.5\%). Sedangkan dari 23 responden dengan aktifitas fisik sering dengan personal hygiene bersih yaitu sebanyak 6 responden (26.1 \%). Hasil uji statistik Chi-square diperoleh nilai $P$-value $=0,024$ dimana nilai $P$-value $<\alpha(0,05)$ sehingga dapat disimpulkan bahwa terdapat hubungan aktifitas fisik terhadap personal hygiene saat menstruasi pada remaja putri Di SMK Kusuma Bangsa Bogor tahun 2020. Nilai P-value didapatkan dari Continuity Correction karena berdasarkan hasil pengolahan program SPSS didapatkan keterangan dari tabel 2x2 tidak terdapat nilai expected count kurang dari 5, dan memiliki nilai Odds Ratio sebesar 4.156 artinya responden dengan aktifitas fisik sering memiliki peluang 4 kali untuk memiliki personal hygiene bersih dibandingkan dengan responden dengan aktifitas fisik tidak sering

Dari 31 responden dengan orang tua yang tidak berperan dalam personal hygiene dengan personal hygiene bersih yaitu sebanyak 23 responden (74.2\%). Sedangkan dari 29 responden dengan orang tua berperan dengan personal hygiene bersih yaitu sebanyak 5 responden (17.2\%). Hasil uji statistik Chi-square diperoleh nilai $P$-value $=0,000$ dimana nilai $P$-value $<\alpha(0,05)$ sehingga dapat disimpulkan bahwa terdapat hubungan peran orang tua terhadap personal hygiene saat menstruasi pada remaa putri di SMK Kusuma Bangsa Bogor tahun 2020. Nilai P-value didapatkan dari Continuity Correction karena berdasarkan hasil pengolahan program SPSS didapatkan keterangan dari tabel 2x2 tidak terdapat nilai expected count kurang dari 5, dan memiliki nilai Odds Ratio sebesar 13.800 artinya responden dengan orang tua yang tidak berperan memiliki peluang 14 kali untuk memiliki personal hygiene kurang bersih dibandingkan dengan respon dengan personal hygiene bersih. 


\section{SIMFISIS Jurnal Kebidanan Indonesia}

Volume 01, Nomor 01, Agustus 2021

Dari 34 responden dengan yang tidak mendapatkan sumber informasi dengan personal hygiene bersih yaitu sebanyak 22 responden (64.7\%). Sedangkan dari 26 responden yang mendapatkan sumber informasi dengan personal hygiene bersih yaitu sebanyak 6 responden $(23.1 \%)$. Hasil uji statistik Chisquare diperoleh nilai $P$-value $=0,003$ dimana nilai $P$-value $<\alpha(0,05)$ sehingga dapat disimpulkan bahwa terdapat hubungan sumber informasi terhadap personal hygiene saat menstruasi pada remaja putri di SMK Kusuma Bangsa Bogor tahun 2020. Nilai P-value didapatkan dari Continuity Correction karena berdasarkan hasil pengolahan program SPSS didapatkan keterangan dari tabel 2x2 tidak terdapat nilai expected count kurang dari 5, dan memiliki nilai Odds Ratio sebesar 6.111 artinya responden dengan tidak mendapat sumber informasi memiliki peluang 6 kali untuk memiliki personal hygiene kurang bersih dibandingkan dengan responden dengan memiliki personal hygiene bersih.

\section{Pembahasan}

\section{Hubungan aktifitas fisik dengan personal hygiene saat menstruasi pada remaja putri}

Dari hasil penelitian yang dilakukan di SMK Kusuma Bangsa Bogor tahun 2020 terhadap 60 responden di dapatkan bahwa Aktifitas Fisik yang tidak sering dilakukan sebanyak 37 responden $(61,7)$. Sedangkan yang sering melakukan aktifitas fisik yaitu sebanyak 23 responden $(38,3 \%)$. Hasil penelitian menunjukan bahwa tidak sering melakukan aktifitas fisik dapat memepengaruhi personal hygiene yaitu sebanyak 37 responden $(61,7 \%)$. Berdasarkan hasil penelitian ini di dapatkan bahwa ada hubungan antara aktifitas fisik dengan personal hygiene saat menstruasi pada remaja putri dengan $(\mathrm{P}=0.024)$. hal ini juga memperlihatkan bahwa seseorang akan mengalami personal hygiene yang kurang baik apabila ia melakukan aktifitas fisik yang kurang baik. $(\mathrm{OR}=4.156)$.

Hal ini sesuai dengan teori WHO (2013) bahwa aktifitas fisik adalah setiap gerakan tubuh yang di hasilkan oleh otot rangka yang memerlukan pengeluaran energi. Aktifitas fisik yang kurang merupakna faktor resiko independen untuk berbagi penyakit kronis. Aktifitas fisik yang kurang merupakan salah satu upaya untuk menyeimbangkan antara pengeluaran dan pemasukan zat gizi terutama sumber energi tubuh dan memperlancar sistem metabolisme di dalam tubuh termasuk metabolisme zat gizi. Selain itu, aktifitas fisik juga berperan dalam mempengaruhi proses hormon reproduksi Aktifitas fisisk di definisiskan sebagai gerakan anggota tubuh ysng di produksi oleh kontraksi otot sehingga menghasilkan otot yang berungsi untuk memelihara kesehatan fisik dan mental serta memepertahankan kualitas hidup agar tetap sehat dan bugar sepangjangn hari. aktifitas fisik seperti olahraga, berjalan kaki juga dapat memepengaruh personal hygine jika tidak dijaga dengan baik terutama pada saat menstruasi kuman dan bakteri dapat dengan mudah masuk kedalam tubuh

Teori Giriwijoyo dkk (2012) juga mengungkapkan bahwa aktifitas fisik adalah setiap gerakan tubuh yang membutuhkan energi untuk mengerjakannya. Sedangkan olahraga merupakan aktifitas fisik yang terencana dan terstruktur serta melibatkan gerakan tubuh berulang - ulang dan bertujuan untuk meningkatkan kebugaran jasmani. Apabila seseorang tidak melakukan aktifitas fisik dengan baik bias menebabkan kebersihan diri juga kurang baik. Adapun penelitian yang di lakukan Stefany dan Emi 2018 di dapatkan hasil bahwa aktifitas fisik terhadap kebersiha diri saat menstruasi di dapatkan hasil $\mathrm{p}$ Value 0,030 yang berarti $\mathrm{p}<0,005$ sehingga dapat disimpulkan bahwa ada hubungan antara aktifitas fisik terhadap kebersihan diri saat menstruasi pada remaja. Asal kata personal hygiene dari bahasa Yunani, personal mempunyai arti individu atau seseorang dan hygiene memiliki makna bersih atau sehat (Mubarak dan Chayaning, 2008). Maksud dari dua kata tersebut adalah usaha dari setiap manusia yang wajib dilakukan dalam keseharian guna terpeliharanya kebersihan serta kesehatan diri, terkait secara fisik maupun psikologis. Dengan demikian, perawatan terhadap tubuh harus dibiasakan minimal dengan mandi dua kali dalam sehari. Menjaga kesehatan perineal juga penting terlebih ketika menstruasi. Hal ini perlu karena pada saat menstruasi, kuman dan bakteri mudah masuk dan dapat menginfeksi organ vital perempuan. Personal hygiene merupakan salah satu faktor eksternal yang dapat merubah keseimbangan PH vagina ditandai dengan penggunaan celana dalam yang terlalu ketat maupun perilaku personal hygiene yang buruk lainnya (Dewi A.L, 2014). Dampak yang dapat terjadi 


\section{SIMFISIS Jurnal Kebidanan Indonesia}

Volume 01, Nomor 01, Agustus 2021

jika seseorang kurang memperhatikan kebersihan organ genetalia saat menstruasi dalam waktu dekat akan mudah mengalami demam, gatal-gatal pada kulit vagina, radang pada permukaan vagina, keputihan, rasa panas atau sakit pada bagian bawah perut (Yuni, 2015). Selain itu dampak yang ditimbulkan jika memiliki personal hygiene buruk adalah terkena kanker leher rahim karena kesalahan dalam arah membersihkan vagina saat selesai buang air besar maupun air kecil.

Perawatan genetalia merupakan bagian dari mandi lengkap, perawatan genetalia di lakukan untuk mencegah terjadinya infeksi, mempertahankan kebersihan genetalia, meningkatkan kenyamanan serta mempertahankan kebersihan genetalia, meningkatkan kenyamanan serta mempertahankan personal hygiene. Menurut Burns pada saat mentruasi, pembulu darah dalam rahim mudah terkena infeksi. Oleh karena itu kebersihan vagina harus dijaga karena kuman mudah sekali masuk dan dapat menimbulkan penyakit pada saluran reproduksi. Beberapa penyakit yang mudah hinggap pada wanita saat menstruasi adalah infeksi jamur dan bakteri salah satunya adalah vaginitis. Vaginitis (peradangan pada vagina adalah salah satu yang paling sering dikeluhkan oleh wanita). Gejalah seperti pruritus vulva, iritasi, inflamasi, sekresi vagina, dan rasa perih biasanya diakibatkan oleh salah satu organisme berikut : Candida Albicans, Thrichomoniasis vaginalis, dan Gardnerella vaginalis,sekitar dari $25 \%$ kasus yang ada disebabkan oleh Candida Albicant dan Thrichomoniasis vaginalis dan sisanya oleh G. Vaginalis salah satu penyebabnya dalah bakteri pada pembalut yang kurang berkualitas sehingga pembalut tersebut menjadi media perkembangbiakan bakteri yang merugikan kaum wanita

Dalam pemilihan pembalut sebaiknya pilih pembalut yang berbahan lembut.dapat menyerap dengan baik dan permukaan yang lembut, tidak mengandung bahan yang buat alergi dan iritasi pada daerah kulit vagina dan merekat dengan baik pada pakaian dalam dan untuk menjaga kebersihan genetalia pembalit secara teratur $4-5$ kali sehari diganti, setelah buang air kecil dan buang air besar dan sewaktu mandi. Hasil penelitian Handayani (2018) menunjukkan perilaku hygiene saat menstruasi, diproleh score tertinggi 25 dan score terendah 19 dengan rata-rata nilai 22,20. Menunjukan bahwa sebagian besar perilaku vulva hygiene saat menstruasi pada remaja putri di Ponpes Al-Gfifari Gamping Sleman cukup baik. Perilaku hygiene saat menstruasi adalah suatu usaha atau tindakan mempertahankan atau memperbaiki kesehatan dengan memelihara kebersihan alat reproduksi saat menstruasi. Menjaga kesehatan berawal dari menjaga kebersihan. Hal ini berlaku juga bagi kesehatan seksual, termaksud vagina.

Peneliti berasumsi bahwa dengan perkembangan teknologi yang sangat pesat dan juga semakin minimnya ruang terbuka terutama di kota besar, terjadi pula penurunan aktifitas fisik pada remaja. Remaja lebih suka menghabiskan waktu dengan bermain gatget dibandingkan dengan melakukan aktifitas sehari-hari. Salah satu dampak dari kurangnya aktifitas fisik adalah terjadinya obesitas dan kurangnya kebersihan diri seperti malas mandi. Aktifitas fisik merupakan salah satu upaya untuk menyeimbangkan antara pengeluaran dan pemasukan zat gizi utamanya sumber energi tubuh dan memperlancar sistem metabolisme dalam tubuh termasuk metabolisme zat gizi. Aktifitas fisik berperan dalam menyeimbangkan zat gizi yang keluar dan yang masuk, yang mempengaruhi juga pada proses hormon reproduksi.

Besarnya juga aktifitas fisik yang tidak sering pada remaja dalam penelitian ini disebankan karena saat ini merupakan zaman perkembangan teknologi dimana suatu hal sudah di permudah dengan teknologi sehingga mengurangi pergerakan tubuh dalam bentuk aktifitas fisik. Jika ingin berpergian kesuatu tempat yang dekat saja hanya saja tinggal berpesan transportasi online, selain itu melakukan berbagai aktifitas lain juga bisa dilakukan melalui teknologi seperti internet, contohnya ketika ingin membeli makanan memesan atau mengantar barang, membersihkan rumah dan masih banyak lagi, aktifitas lain yang di bantu oleh orang lain melalui teknologi. Dengan adanya kemudahan tersebut seseorang menjadi cenderung malas untuk bergerak. Perkembangan teknologi juga membuat remaja menghabiskan banyak waktu di depan layar gatget hingga malas untuk melakukan hal lain yang berkaitan dengan gerak tubuh (aktifitas fisik). Oleh sebab itu karena aktifitas fisik berhubungan dengan kurangnya personal hygiene yang baik dan benar sehingga ketika seseorang yang tidak aktif secara fisik dalam melakukan aktifitas fisik maka mereka lebih cenderung untuk malas mandi dan malas mengganti pakaian atau celana dalam karena mereka menganggap bahwa badan mereka masih bersih dan dan 


\section{SIMFISIS Jurnal Kebidanan Indonesia}

Volume 01, Nomor 01, Agustus 2021

pakaian mereka masih bersih. Berbeda degan remaja yang sering melakukan aktifitas fisik, mereka lebih rajin mandi dan mengganti pakaiannya karena mereka merasa sudah berkeringat dan dan pakaiannya sudah tidak enak di pakai sehingga mereka lebih cepat membersihkan badannya. Melihat rendahnya aktifitas remaja yang aktif ini maka remaja harus menumbuhkan kesadaran dalam dirinya untuk melakukan aktifitas tubuh, ini tidak harus dilakukan dengan aktifitas fisik yang berat cukup dengan melakukan aktifitas fisik yang sedang saja yang di lakukan secara rutin, seperti membersihkan rumah setiap hari, berjalan santai di pagi hari menyiram kebun dan membersihkan kamarmandi, ber aktifitas fisik setiap hari seperti membersihkan halaman rumah dan melakukan aktifitas fisik setiap harinya seperti bersepeda santai karena aktifitas fisik yang baik ber manfaat untuk kesehatan tubuh terutama bagi remaja yang sedang memasuki tahap perubahan dalam hidupnya yaitu pubertas.

\section{Hubungan peran orang tua dengan personal hygiene saat mestruasi paada remaja putri}

Dari hasil penelitian yang dilakukan di SMK Kusuma Bangsa Bogor tahun 2020 terhadap 60 responden di dapatkan orang tua yang tidak berperan dalam personal hygiene sebanyak 31 responden $(51,7 \%)$. Sedangkan yang berperan yaitu sebanyak 293 responden $(48, \%)$. Hasil penelitian menunjukan bahwa lebih banyak orang tua yang tidak berperan dalam hal personal hygiene yaitu sebanyak 31 responden $(51,7 \%)$. Berdasarkan hasil penelitian ini di dapatkan bahwa ada hubungan antara peran orang tua dengan personal hygiene saat menstruasi pada remaja putri dengan $(\mathrm{P}=0.000)$. Hal ini juga memperlihatkan bahwa seseorang akan mengalami personal hygiene yang kurang baik apabila orang tua kurang berperan dalam memberkan pengetahuan tentang personal hygiene. $(\mathrm{OR}=13.800)$

Hasil penelitian ini diperkuat oleh teori Dianawati 2010 bahwa orang tua merupakan pihak pertama yang bertanggung jawab memberikan inormasi tentang kesehatan reproduksi bagi remaja. Remaja yang kurang informasi tentang kesehatan reproduksi di khawatirkan tidak dapat melakukan personal hygiene yang baik dan benar terutama saat menstruasi. Padahal masalah kesehatan reproduksi terjadi justru akibat remaja kekurangan informasi yang benar dan bertanggung jawab sehingga mereka mengakes inormasi yang keliru. Peran ibu adalah tingkah laku yang telah melahirkan atau mengadopsi seseorang dalam keluarga, bersikap keibuan, lemah lembut dan penh kasih sayang ibu mempunyai peran penting dalam memberikan sumber inormasi tentang kebersihan diri atau personal hygiene kepada anak gadisnya khususnya tentang menstruas. Ibu juga harus memberikan contoh yang baik dan bersiat terbua selalu siap dalam menjawab pertanyaan yang diajukan anak sesuai kemampuannya..

Perilaku vulva hygine pada saat menstruasi dikenal sebagai salah satu yang memberikan pengaruh paling kuat terhadap kelangsungan hidup anak karena berkaitan dengan organ vital anak, pertumbuhan dan perkembangan. Peran orang tua berperan dalam mempengaruhi ibu untuk memberikan pengaruh tentang perilaku vulva hygine pada saat menstruasi, senada peran orang tua sebagai lingkungan pertama dan utama dimana anak-anak berinteraksi sebagai lembaga pendidikan yang tertu, artinya disinilah dimulai suatu proses pendidikan. Sehingga orang tua berpesan sebagi pendidik bagi anak-anaknya. Lingkungan keluarga juga dikaitkan dengan lingkungan yang paling utama, karena sebagian besar kehidupan anak di dalam keluarga, sehngga pendidikan yang paling banyak di terima anak adalah keluarga. Menurut hasbullah (1997), dalam tulisannya tentang dasardasar ilmu pendidikan, bahwa keluarga sebagai lembaga pendidikan memiliki beberapa fungsi yaitu fungsi dalam perkembangan kepribadian anak dan mendidik anak dirumah. Orang tua didarapkan dapat melayani kebutuhan anak dalam rangka membina dan mengembangkan kemampuan anak serta kpribadian anak. Kultur di indonesia yang menyerahkan pengasuhan anak pada ibu seharusnya bukan merupakanalasan bagi ayah untuk tidak turut serta dalam proses pengasuhan anak, karena pengasuh anak merupakan tanggung jawab bersamakedua orang tua meskipun pada tahun pertama kehidupan peran ayah tidak sebesar peran ibu karena anak masih sangat tergantung pada ibunya. Secara garis besar ibu perlu mengetahui kebutuhan anak secara umum seperti : kebutuhan pendampingan pada saat menstruasi, kebutuhan pengetahuan pada saat menstruasi dan guru pertama dalam pemberian perilaku vulva hygine. 


\section{SIMFISIS Jurnal Kebidanan Indonesia}

Volume 01, Nomor 01, Agustus 2021

Manuaba (2009), menyatakan bahwa infeksi yang terjadi pada organ direproduksi dapat mengakibatkan infertile (kemandulan) dan meningkatkan angka kejadian kehamilan ektopik terganggu atau kehamilan yang berada di luar kandungan. Oleh karena adanya penyakit tersebut, orang tua mempunyai andil yang besar guna menanamkan pemahaman terkait kesehatan pada reproduksi terhadap anak. Remaja putri pun demikian, tentunya lebih berterus terang pada orang tua mengenai permasalahan kesehatan organ reproduksi, bertanya pada orang tua atau guru sekolah jika mengalami kejadian yang membuat tidak nyaman menghadapi menstruasi beserta upaya untuk menanggulangi ketidaknyamanan tersebut. Komunikasi efektif antara orang tua dan anak merupakan suatu proses penyampaian

informasi yang dilandasi oleh sikap saling percaya, terbuka, dan berbagai dukungan positif (Rakhmat, 2013). Dengan adanya sikap tersebut, maka diharapkan dapat mengurangi berbagai keluhan yang dihadapi remaja.

Penelitian yang dilakukan Ayu fitria mustika, (2015) di dapatkan hasi bahwa peran orang tua terhadap personal hygiene saat menstruasi di dapatkan hasil $\mathrm{P}$ Value $=0,000<0,05$ sehingga dapat di simpulkan adanya hubungan antara peran orang tau dengan personal hygiene saat menstruasi pada remaja putri. ${ }^{13}$ Adapun penelitian yang dilakukan oleh Anna, Dkk, (2018) di dapatkan bahwa hubungan peran orang tua terhadap personal hygiene saat menstruasi di dapatkan hasil $\mathrm{P}$ Value $=0,002<0,005$ ) sehingga dapat disimpulkan bahwa ada hubungan antara peran orang tua terhadap personal hygiene saat menstruasi pada remaja putri. ${ }^{14}$ Dukungan sosial dan emosional orangtua terhadap menarche memberikan kontribusi untuk kesejahteraan emosional selama masa remaja dan penyesuaian pubertas yang positif di kalangan remaja putri

Berdasarkan hasil penelitian peneliti berasumsi bahawa peran orang tua sangatlah penting terutama peran ibu bagi remaja putri dalam memberikan informasi tentang kebersihan diri atau personal hygiene terutama saat menstruasi. orang tua juga harus memiiki pengetahuan tentang kesehatan reprouksi yang memadai sehingga dapat menyampaikan kepada anak gadisnya dengan baik dan benar, peran orang tua tidak hanya sebagai pendidik, pengawas, pendorong, teman dan konselor tetapi seebagai orang tua harus memberikan contoh yang baik dan benar kepada anaknya dan menasehati anaknya dalam hal pergaulan.

\section{Hubungan sumber informasi dengan personal hygiene saat menstruasi pada remaja putri}

Dari hasil penelitian yang dilakukan di SMK Kusuma Bangsa Bogor tahun 2020 terhadap 60 responden di dapatkan bahwa yang tidak mendapatkan sumber informasi tentang personal hygiene saat menstruasi sebanyak 34 responden $(56,7 \%)$. Sedangkan yang mendapatkan sumber informasi yaitu sebanyak 26 responden (43,3\%). Hasil penelitian menunjukan bahawa masih banyak siswi yang tidak mendapatkan sumber informasi yaitu sebanyak 34 responden $(56,7 \%)$.

Berdasarkan hasil penelitian ini di dapatkan bahwa ada hubungan antara sumber informasi terhadap personal hygiene saat menstruasi pada remaja putri dengan $(\mathrm{P}$ Value $=0.003)$. Hal ini juga memperlihatkan bahwa seseorang akan mengalami personal hygiene yang kurang baik apabila ia tidak menapatkan sumber inormasi yang baik dari orang tuanya, guru maupn tenaga kesehatan, buku dan social media yang kurang baik. $(\mathrm{OR}=6.111)$ Hasil penelitian ini diperkuat oleh teori Notoatmodjo 2012 bahwa sumber informasi adalah media yang berperan bertindak. Sumber informasi adalah segala sesuatu yang menjadi perantara dalam menyampaikan informasi, media informasi untuk peran keluarga. Sumber informasi dapat di peroleh melalui media cetak (surat kabar, majalah) media elektronik (televisi, radio, internet) dan melalui kegiatan tenaga kesehatan seperti pelatihan yang diadakan. Sumber informasi yang berasal dari media elektronik, media cetak, keluarga, petugas kesehatan sangat berpengaruh pada pola pikir seseorang. Usulan dari pemerintah menyebarluaskan informasi tentang personal hygiene yang benar dan dampak apabila tidak melakukan personal hygiene secara baik dan benar. $^{15}$

Sumber informasi adalah segala sesuatu yang menjadi perantara remaja dalam mendapat informasi tentang perilaku personal hygine saat menstruasi pada remaja dengan indikator media cetak, 
media elektronik, dan petugas kesehatan. Teori Lestariningsi juga mengungkap bahwa sumber informasi dari media masa dan elektonik mengangkat masalah kesehatan reproduksi termasuk di dalamnya tentang personal hygiene saat menstruasi. Iklan- iklan yang berkaita dengan menstruasi baik iklan tentang pembalut wanita ataupun obat-obatan yang berkaitan dengan masalah-masalah gangguan haid bannyak di tayangkan oleh media masa, media elektronik dan media cetak. ${ }^{16}$

Sedangkan teori Samsuri, dkk, (2016) mengungkapkan bahwa sumber informasi yang di berikan oleh tenaga kesehatan adalah upaya untuk meningkatan upaya kesehatan perorangan paling sedikit mengenai pengolahan factor resiko penyakit dan perilaku hidup bersih dan sehat, mencegah timbulnya penyakit dan memulihkan penyakit. Sumber informasi dari tenaga kesehatan terkait dengan personal hygiene saat menstruasi sangat penting agar dapat meningkatkan pengetahuan remaja terutama bagi remaja putri yang baru menstruasi, mendapatkan informasi dari tenaga kesehatan tentang kebersihan diri saat menstruasi merupakan hal vital pendidikan kesehatan, sehingga akan terus berperilaku menjaga kebersihan saat menstruasi sampai usia dewasa bahkan sampai menopause. Penelitian yang dilakukan Meinasari pada tahun 2019 di dapatkan hasil bahwa sumber informasi dengan personal heygine saat mentruasi di dapatkan $\mathrm{P}$ Value $=0,001<0,005$ sehingga dapat disimpulan bahwa ada hubungan yang bermakna antara sumber informasi dengan personal hygiene saat menstruasi.

Adapun Penelitian yang dilakukan oleh Aulia Anjani dkk, tahun 2018 di dapatkan bahwa sumber inormasi dengan personal hygiene saat menstruasi di dapatkan $\mathrm{P}$ Value $=0,000<0,005$ sehingga dapat disimpulkan adanya hubungan sumber inormasi dengan personal hygiene saat menstruasi pada remaja putri. Hasil penelitian ini tidak didukung oleh penelitian Avianty (2020) dengan hasil penelitian menunjukkan bahwa sumber informasi responden mengenai tingkat pengetahuan terhadap kebersihan organ genital yaitu sebanyak 90 responden atau sekitar 65,7,\% terpapar informasi mengenai kebersihan organ genital dibandingkan dengan responden yang tidak terpapar mengenai kebersihan organ genital pada remaja putri yaitu sebanyak 47 responden atau sekitar 34,3\%. Berdasarkan hasil uji statistik didapatkan bahwa nilai $p$ value $=0,593$ yang berarti tidak terdapat hubungan yang bermakna antara sumber informasi dengan tingkat pengetahuan remaja putri mengenai kebersihan organ genital.

Akanksha (2014), melakukan penelitian pada remaja putri di pedesaan, ditemukan hasil bahwa pengetahuan tentang menstruasi pada remaja putri tidak memuaskan. Remaja putri harus diberi pengetahuan tentang proses menstruasi dan juga tentang kebersihan selama menstruasi untuk dapat menjaga kesehatan mereka. Hasil penelitian Wijaya (2014) menunjukkan bahwa remaja yang memiliki pengetahuan dan sikap yang baik akan diikuti dengan aktivitas yang positif juga. Sumber informasi adalah data yang di peroses dalam suatu bentuk yang memepunyai arti bagi penerima dan mempunyai nilai nyata dan terasa bagi keputusan saat ini atau keputusan mendatang, informasi yang datang dari pengiriman pesan yang ditujukan kepaa penerima pesan. selain itu informasi dapat di peroleh dari media cetak, media elektronik, non media, keluarga orang lain, tenaga kesehatan.

Sumber informasi adalah media yang berperan penting bagi seseorang dalam menentukan sikap dan keputusan untuk bertindak. Sumber informasi itu dapat di peroleh dengan bebas mulai dari perorangan, buku, film, video, bahkan dengan mudah membuka dengan situs - situs lewat internet. Informasi yang diperoleh dari berbagai sumber akan mempengaruhi tingakat seseorang. Bila seseorang banyak memeperoleh informasi maka individu tersebut cenderung mempunyai pengetahuan yang luas. Semakin sering orang membaca penngetahuan akan semakin baik dari pdada hanya sekedar mendengar atau melitah saja. Dan dapat dibuktikan dengan banyak minat memebaca. Banyak penelitian telah mengungkapkan bahwa ibu, guru, teman, kakak, media massa adalah sumber utama dalam memberikan informasi tentang menstruasi untuk remaja. Ibu adalah sumber informasi yang paling utama tentang kebersihan menstruasi, diikuti dengan media massa, kakak, teman-teman dan guru. Hasil penelitian yang dilakukan Dhingra, (2009) menunjukkan bahwa adanya larangan sosial dan sikap negatif orang tua dalam membahas isu-isu terkait secara terbuka telah menghambat akses remaja untuk informasi yang tepat. Jika ibu mengkomunikasikan pandangan yang positif tentang menstruasi, maka remaja putri juga akan memiliki pandangan yang positif. Tetapi jika ibu memberikan pandangan yang negatif, 


\section{SIMFISIS Jurnal Kebidanan Indonesia}

Volume 01, Nomor 01, Agustus 2021

remaja putri lebih mungkin untuk mempunyai pandangan yang sama tentang menstruasi (Marvan, 2012).

Aktifitas dan perilaku seksual remaja banyak di pengaruhi oleh teknologi, seperti media cetak, dan media elektronik. remaja mudah memperoleh hal-hal porno dari majalah, novel, televises, ved dan internet. Juga bahkan dari cerita orang tentang yang berbau porno. sedangkan remaja cenerung untuk meniru dan mencoba-coba hal yang baru demi menjawab rasa penasaran mereka. Banyak remaja yang mendapat informasi tentang kesehatan reproduksi karena media masa merupakan media yang menyediakan informasi secara bebas walaupun informasi itu ada dan positif atau ada pula yang negative. Terjadi akulturasi budaya terutama budaya asing yang menganut kehidupan bebas, di sebaban oleh kehadiran media cettak, telefisis, dan filem media masa merupakan salah satu wadah bagi remaja untuk meneyerap informasi.

Media masa adalah alat yang digunakan untuk menyampaikan pesan dari sumber kepada khalayak dengan menggunakan alat-alat komunikasi seperti surat kabar, novel, filem, radio TV. Media masa dibagi menjadi dua yaitu: media cetak dan media elektronik meia cetak terdiri dari surat kabar, mejalah, tabloid, sedangkan media elektronik adalah televise dan radio. Media masa merupakan alat alat komunkasi yang dapat menyebabkan perilaku seseorang. Media masa merupakan alat komukasi yang dapat dengan cepat dapat menyampaikan pesan secara serempak, cepat kepada audiens ang luas dan heteroge. Kelebihan media masa dibandingkan dengan jenis komunikasi lainnya adalah media masa yang dapat menghambat ruang dan waktu bahkan media masa dapatmeneyebar pesan pada waktu seketika dan pas waktu yang tak terbatas. Media komukasi berperan sangat penting sebagai alat Untuk menyampaikan informasi yang nantinya diharapkan dapat nengubah perilaku yang berkaitan dengan kesehatan dan pengetahuan tentang penyakit - penyakit. Media masa adalah perpanjangan alat indra (sense extian teori, teori perpanjangan alat indra). dengan media masa khalayak memperoleh tentang benda, orang atau tempat yang belum pernah dilihat atau dikunjungi secara langsung. Dunia ini terlalu luas untuk dimasuki semuanya.maka media masa dating untuk menyampaikan inormasi sehingga televise menjadi jendela kecil untuk menyampaikan berbagai peristiwa yang jauh dari jangkauaan panca indra.

Realitas yang di tampilkan oleh media masa adalah realitas yang sudah di seleksi. Khalayak cenderung memperoleh informasi tersebut semata - mata berdasarkan paa apa yang dilaporkan media masa. Hasil khalayak membemtuk citra tentang lingkungan social berdasarkan realitas kedua yang di tampilkan dimedia masa. Karena televisi sering menyajikan adegan kekerasan, penonton televises cenderung mememandang dunia ini lebih keras, lebih tidak aman dan lebih mengerikan. Karena media masa melaporkan dunia nyata secara efektif, maka sudah tentu media masa memepengaruhi pembentukan citra tentang lingkungan soaial yang biasa dan simpang. Oleh karena itu, muncul apa yang disebut steotif yaitu gambaran umum tentang individu, kelompok, profisi, atau masyarakat ang tidak berubah - ubah. Bersifat klise dan sering simpang dan tidak benar. Penelitian Gustina dan Djannah (2015) menunjukkan hubungan yang signifikan antara sumber informasi dengan pengetahuan dengan nilai $\mathrm{p}<0,05$. Simpulan penelitian, ada hubungan antara sumber informasi dengan pengetahuan tentang menstrual hygiene pada remaja.

Berdasarkan hasil penelitian, peneliti berasumsi bahwa personal hygiene sangat penting terutama saat menstruasi, jika tidak melakukan personal hygiene yang baik dan benar bisa menyebabkan gangguan reproduksi seperti keputihan dan infeksi saluran reproduksi. Maka dari itu sumber inormasi sangat penting bagi remaja baik itu sumber infermasi dari media masa media elektronik, tenaga kesehatan ataupun dari orang tua mereka. Dengan adanya media elektronik Remaja putri juga dapat mencari informasi tentang kebersihan diri atau personal hygiene dengan mudah.

\section{Kesimpulan}

Kesimpulan dari penelitian ini yaitu Terdapat hubungan yang bermakna menegenai aktifitas fisik terhadap personal hygiene saat menstruasi sebesar $p$ Value 0,024 dan Odd Rasio (OR) 4.156 remaja putri yang dalam keluarganya orang tuanya tidak berperan terhadap kebersihan putrinya 


\section{SIMFISIS Jurnal Kebidanan Indonesia}

Volume 01, Nomor 01, Agustus 2021

terutama saat menstryasi berpeluang mengalami personal hygiene yang kurang baik sebesar $\mathrm{p}$ Value 0,000 Odd Rasio (OR) 13.800 dan remaja putri yang tidak pernah mendapatkan sumber informasi dengan baik berpeluang mengalami kebersihan diri kurang baik sebesar $p$ Value $=0,003$ dan Odd Rasio (OR) 6.111 .

\section{Konflik Kepentingan}

Menyatakan bahwa penelitian ini independen dari konflik kepentingan individu dan organisasi

\section{Ucapan Terima Kasih}

Terimakasih kepada semua responden dan semua pihak yang mendukung penelitian ini.

\section{Pendanaan}

Sumber pribadi

\section{References}

1. Gustina E, Djannah SN. Sumber Informasi Dan Pengetahuan Tentang Menstrual Hygiene Pada Remaja Putri. J Kesehat Masy. 2015;10(2):147.

2. Pythagoras KC. Personal Hygiene Remaja Putri Ketika Menstruasi. J promkes. 2017;5(1):56173.

3. Proverawati, A., Misaroh S. Menarche Menstruasi Pertama penuh Makna. Yogyakarta: Nuha Medika; 2009.

4. Handayani S. HubunganTingkat Pengetahuan Personal Hygine Dengan Perilaku Vulva Hygine Saat Menstruasi Pada Remaja Putri Di Ponpes Al - Ghifari Gamping Sleman Yogyakarta. J Kesehat Samodra Ilmu. 2018;10(1):2-3.

5. WHO. Pertumbuhan Remaja di Negara Berkembang [Internet]. 2013 [cited 2019 Nov 20]. Available from: http://www.who.int/topics/en/indeks/ret\%0Arieved\%0D

6. Dinas Kesehatan. Program Kesehatan Reproduksi [Internet]. Jakarta; 2014. Available from: http:www.depkes.co.id

7. Avianty I. Faktor-Faktor Yang Berhubungan Dengan Tingkat Genital Di Pondok Pesantren Darussalam Kabupaten Bogor. Promot J Mhs Kesehat Masy. 2020;3(1):56-63.

8. Wulandari RF. Hubungan Pengetahuan Remaja Putri Usia 13-16 tahun tentang Perawatan Alat Reproduksi Eksternal dengan Perilaku Merawat Alat Reproduki Eksternal. J Ilm Keperawatan Indones. 2012;2(1).

9. Anisa M. hubungan peran orang tua perilaku perawatan genetalia eksternal saat menstruasi pada remaja di SMPN Boyolali. 2018;

10. Notoatmodjo. Metode Penelitian. Jakarta: Rineka Cipta; 2015.

11. Giriwijoyo. Ilmu Kesehatan Olahraga. Cetakan Pertama. Bandung: Posda; 2012.

12. Dianawati. Pendidikan Seks Pada Remaja. Jakarta: Kawan Pustaka; 2010.

13. Ayu Fitria Mustika. Hubungan Peran Ibu Dengan Perilaku Perawatan Diri Saat Menstruasi. Stikes Asyiyah Yogjakarta. 2015;

14. Anna. Hubungan Peran Ibu Dengan Perilaku Hygine Menstruasi Pada Remaja Putri. J UNISA. 2018;

15. Notoatmodjo. Pendidikan Dan Perilaku Kesehatan. Jakarta: Rineka Cipta; 2012.

16. Lestariningsih. Faktor-Factor Yang Berhubungan Dengan Praktek Hygine Menstuasi. J Kesehat Poltekes Tanjung Karang. 2015; 